\title{
Mindfulness and Its Absence - The Development of the Term Mindfulness and the Meditation Techniques Connected to It from Daoist Classics to the Sinicized Buddhism of the Chan School
}

\author{
Jana S. ROŠKER*
}

\begin{abstract}
This article addresses the modifications of the term mindfulness in sinicized meditation practices derived from Indian Buddhism. It attempts to shed some light on these modifications from two different aspects: first the classical Daoist meditation practices were analysed, and this showed why and in what way did the Daoist terminology function as a bridge in the initial phase of translating Buddhist concepts and the sinicization of Buddhist philosophy. The second aspect focused on the concept of mindfulness. The author addressed the development of the original etymological meaning and the later semantic connotations of the concept nian 念, which-in most translated literature--represents synonyms for the term sati (Pāli) or smrti (Sanskrit), from which it is translated into awareness (in most Indo-European languages) or mindfulness (in English). Based on the analysis of these two aspects the author showed the specifics of the modification of the term mindfulness in Chinese meditative practices as they were formed in the Buddhism of the Chan 禪 School. The various understandings of this concept are shown through the contrast of the interpretations of the notion of nian 念 in the North and South Schools of Chan Buddhism.
\end{abstract}

Keywords: sinicization of Buddhism, Chan, Chinese concept of mindfulness, nian, Daoism

\section{Izvleček}

Pričujoči članek obravnava modifikacije pojma čuječnosti v siniziranih meditacijskih praksah izvorno indijskega budizma. Te modifikacije poskuša osvetliti z dveh zornih kotov: prvič s pomočjo analize klasičnih daoističnih meditacijskih praks, pri čemer pokaže, zakaj in na kakšen način je daoistična terminologija pogosto služila kot most pri začetni fazi prevajanja budističnih konceptov in pri sinizaciji budistične filozofije. Drugi vidik se osredotoča na sam koncept čuječnosti, ki ga avtorica obravnava na osnovi analize razvoja

Jana S. ROŠKER, Professor, Department of Asian Studies, Faculty of Arts, University of Ljubljana, Slovenia. jana.rosker[at]ff.uni-lj.si

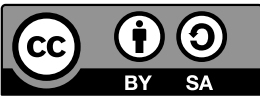


izvornega etimološkega pomena in kasnejših semantičnih konotacij koncepta nian 念, ki je v večini prevodne literature predstavljal sinonim termina sati (pali) oziroma smrti (sanskrt) in ki se $\mathrm{v}$ sodobne indoevropske jezike večinoma prevaja s pojmom čuječnosti (oziroma mindfulness $\mathrm{v}$ angleščini). $\mathrm{Na}$ osnovi rezultatov analize obeh zgoraj omenjenih vidikov avtorica pokaže specifiko modifikacij pojma čuječnosti v kitajskih meditacijskih praksah, kakršne so se oblikovale v budizmu šole Chan 禪. Različna pojmovanja tega koncepta prikaže preko kontrastivne analize interpretacij pojma nian 念 v osrednjih delih Severne in Južne šole Chan budizma.

Ključne besede: sinizacija budizma, Chan, kitajski koncept čuječnosti, nian, daoizem

\section{Classic Daoist Meditation Techniques and the Theoretical Starting- points of the Sinicization of Buddhism}

The term mindfulness was brought to China in the context of Buddhism (Ditrich 2016, 198). The sinicization of the Mahayana Buddhism, which dominates Chinese culture, includes a number of elements taken from classical Chinese thought. Apart from the strictly formal and logical starting points, which were developed during the third century BCE by Gongsun Long, the most important representative of the School of Names and a classic theoretician of Chinese cognitive theory, the contribution of Daoist philosophy and the corresponding meditation practices also played an important role in the sinicization of the Buddhist thought-especially on its practical level and as regards its contents. Thus we could call the sinicization of the original teachings the "Daoisation" of the Buddhist thought, for we cannot imagine the process of spreading and accepting Buddhism in China without the introduction of certain Daoist elements, which have-in a slightly changed form and often merely indirectly_ greatly contributed to the understanding of Buddhism in China.

Classical Daoist terminology played an important role in the sinicization of Buddhism. At first Buddhist philosophy-which emerged in very different historical and cultural conditions-represented "an alien" in traditional Chinese thought, as the Chinese saw the original Indian concepts, which were a product of this "different line of thought", as foreign. The Daoist substantial (for instance the concept of void) and methodological (for instance the concept of negation) notions formed a bridge, which made it possible to bring certain Buddhist ideas which the Chinese found at first alien and hard to understand, closer to Chinese culture and tradition. On the other hand, this also influenced certain changes in the development of Buddhist thought, which will be clearly shown in the example of the concept of mindfulness. 
Generally speaking, most credit for the formation of the aforementioned synthesis of the original Indian and traditional Chinese thought should be given to Huineng, the sixth Chan-Buddhism patriarch, who will be discussed in greater detail at a later stage, and who was undoubtedly the master who perfected the teachings of the sinicized (or Daosised) Chan Buddhism into a new unified thought system. If we look at the concrete historic continuity of this process, we cannot ignore the fact that Huineng was not the only nor the first master of Chan to include Daoist elements into his teachings. This process of synthesising both thoughts started a lot sooner, with the first patriarch of Chinese Chan-Buddhism, Bodidharmo (Damo) and his disciple Huike. They were followed by a line of Chinese Buddhist masters, who have-each in their own way-contributed to the sinicization or Daoization of Buddhism and the development of numerous terms that this teaching included the pride: in this context, the notion of mindfulness (Pāli: sati, Sanskrit: smrti) is no exception.

Classic Daoism reveals numerous meditation techniques, which show the use of methods that are similar to mindfulness or at least represent a basis for its use; already the oldest Daoist classic, Laozi's The classic of the virtuous way (Daode jing) ${ }^{1}$ reveals an explicitly introspective central cognitive method:

Without going out of the door, yet knowing all beneath Heaven;

Without looking through the window, yet catching sight of the Great

Natural Way of Tao.

The farther one goes, the less one knows.

Thus, sages know without travelling,

Seeing all clearly without viewing anything,

Thus, they accomplish all without taking any acquired action. ${ }^{2}$

(Laozi 2015, 47) $)^{3}$.

This insight into the ultimate nature of existence can be achieved by consciously merging intuition and mind into a unified spirit. If we manage to focus on the circulation of the vital potential $q i^{4}$ in our bodies, we will once again feel the inseparable connection with everything that exists, similar to a baby who has not yet lost this kind of consciousness, as it has not yet experienced separation (from its mother and through this the universe):

1 Most researchers of classic Daoism believe that this work emerged in the sixth or fifth century BCE.

2 Hu Xuezhi's translation.

3 不出戶知天下; 不閱牑見天道。其出彌遠, 其知彌少。是以聖人不行而知, 不見而名, 不 為而成。

$4 \quad Q i$ is a notion that belongs to the most complex and hardest to translate concepts of Chinese philosophy. For a more detailed explanation see Rošker 2012. 
When the intelligent and animal souls are held together in one embrace, they can be kept from separating. When one gives undivided attention to the (vital) breath, and brings it to the utmost degree of pliancy, he can become as a (tender) baby ${ }^{5}$. (ibid., 10)

Laozi emphasised that there are masters who have perfected this technique, and who can pass it onto others: "Therefore the sage holds in his embrace the one thing (of humility), and manifests it to all the world" (ibid., 22). ${ }^{8}$

The advantage of preserving this focus and the wholesome unity of body and mind, intellect and intuition, lies in the recognition of the mystical, transcendental dimensions of living, in the access to a sphere that surpasses the dividing line of the usual recognition limited to the phenomenal world: "When our consciousness experiences this unit it gains access to the magical sphere of mind" (ibid., 39) ${ }^{9}$.

While Laozi's relativism of opposite units ${ }^{10}$ remained captured within the restraints of conceptual structures which lead to the affirmation of the absolute ${ }^{11}$, the work by Zhuangzi, the second Daoist classic, shows an undeniable urge to surpass this rounded conceptual structure and search for transcendence in a radical annihilation of essence. Zhuangzi wrote:

Being capable of forgetting the difference between the real and unreal is good for the spirit; being true to oneself and not blindly following outer impulses is good for life in society; starting at the appropriate and arriving where nothing remains inappropriate-means forgetting about adjusting to the appropriate (Zhuangzi 2015, Wai pian, Da sheng, 213) ${ }^{12}$.

If we take a closer look at this series of oblivions, which according to Zhuangzi lead to indifference, the floating free state of "wandering at ease" (xiaoyao you), which can be compared to the existence in accordance to self, if we try to empathise with such radical thought of oblivion

\footnotetext{
5 Legge's translation.

6 載營魄抱一, 能無離乎? 專氣致柔, 能嬰兒乎?

7 Legge's translation.

8 聖人抱一為天下式。

9 神得一以靈.

10 Amongst these belongs, for instance, the previously mentioned unit of intuition and reason.

11 Even if this is of a totally different nature than for instance the Ancient Greek idea of the absolute.

12 知忘是非, 心之適也, 不內變, 不外從, 事會之適也, 始乎適而未嘗不適者, 忘適之適也.
} 
we will feel the annihilation of all attachments, including desires and goals. All of this is reminiscent of the endless purity of Chan thoughts. In this sense we can say that Zhuangzi has, in his disputes on oblivion, come close to the limitations of the classic Daoist conceptual structures. (Xu 1996, 220-1) $)^{13}$

Zhuangzi placed the idea of oblivion into the forefront, for it can be found eighty seven times in his True classic. In his text oblivion is related to the sense of the phenomenal world, its forms, expressions, states and consequences. He considered oblivion to be an exit from the frame of thought, a tool which can lead to the straights of the infinitive, which is not limited by the weight and complex network of thoughts, ideas, contexts or conceptuality: "Let's forget time and various views, let's enter infinity and inhabit it!" (Zhuangzi 2015, Neipian, Qiwulun, 12) ${ }^{14}$

Zhuangzi also presented the concept of "sitting in oblivion" (zuo wang), which is reminiscent to meditation techniques performed while sitting down and which lead to the absence of thoughts, conceptual differentiation and unification with the unit of everything living. It is interesting that Zhuangzi presented this technique through a discussion between Confucius and his disciple Yan Hui. The disciple supposedly described "sitting in oblivion" as follows:

What I call sitting in oblivion makes my entire body disappear and my senses become redundant. This is how I separate from my physical form and my knowledge, and become one with the great flow. (ibid., Da zong shi, 9) $)^{15}$

If we are to believe Zhuangzi, Confucius and his pupil also discussed other meditation methods based on techniques similar to mindfulness. One of them is the so-called fasting of the heart-mind ${ }^{16}$ (xin zhai):

13 確實有點破除所有止住, 包括所追求的目標, 那種一無所有的禪味...莊子在這種傳統思維的 基礎上給它注入了更多的超然精神.

14 忘年忘義, 振於無竟, 故寓諸無竟.

15 墮肢體, 黜聰明, 離形去知, 同於大通, 此謂坐忘.

16 In Chinese language the term xin 心, which represents the word that denotes the mind, also denotes the heart as the central organ of the human body. In Chinese tradition the understanding of the human mind was never limited to the perception and functions of categorisations, conceptualisations and thought, but also included feelings and even emotions. At the same time the mind always depended on the existence of the heart as a living organ. In ancient times the Chinese believed that the heart had similar functions to what modern science ascertained are the functions of the brain, which is why in modern sinology this expression in translated into English as the heart-mind. 
Yan Hui asked: "May I ask about the fasting of the heart-mind?" Confucius said: "Concentrate upon your intention! It is better to listen with your heart-mind than to listen with your ears, but better still to listen with your $(q i)$ than to listen with your heart-mind. Listening stops with the ears and the heart-mind stops with matching things up, but ( $q i)$ is tenuous and waits upon things. Only the Way will gather in tenuousness. Tenuousness is the fasting of the heart-mind." ${ }^{17}$ (ibid., Ren jian shi, 2) ${ }^{18}$.

Such fasting of the heart-mind can be seen as a form of mindfulness. The unit of will (i.e. all intentions and desires) is the form of focusing on the here and now and leads to the annihilation of thoughts and mind. Thus this method consequentially leads to the annihilation of self and all its mental limitations; the aforementioned discussion continues as follows:

Yan Hui said: "Before I was able to put this into practice, I was full of thoughts of myself. But now that I am capable of putting it into practice (I realise) that my self has never existed. Can this be called tenuousness?" The Master answered: "You've got it."19 (ibid.) ${ }^{20}$.

The Daoist contribution to the sinicization of the Buddhist thought lies predominantly in the fact that the Daoist classics brought a certain spirit of an eternal transcendental process into the Chinese tradition, and with it they brought a hunch of freedom that can be felt in this process. Celebrating the free naturalness, which should follow the paths of one's own spirit, its free "floating" (xiao yao you), which should be adjusted merely to itself, represents a new, unspecified development possibility, upon which the later theoreticians of sinicized Buddhism were able to develop and fulfil their methodological concepts.

If we take a closer look at the formation process of this new system, we can notice that the early Buddhist masters, who endeavoured for the sinicization of this Indian teaching, almost never directly mentioned the traditional Chinese philosophical classics. Regardless of this they constructed their thought systems with the aid of certain ideas that cannot be found in Indian Buddhism, but which form the central concepts in classic Daoism and Confucianism. These are not formal

17 Translation taken from Edward Slingerland (2003).

18 回曰: 「敢問心齋。」仲尼曰: 「若一志, 无聽之以耳而聽之以心, 无聽之以心而聽之以 氣。聽止於耳, 心止於符。氣也者, 虛而待物者也。唯道集虛。虛者, 心齋也。」

19 Translation taken from Edward Slingerland (2003).

20 顔回曰:「回之未始得使, 實自回也; 得使之也, 未始有回也。可謂虛乎? 」夫子曰: 「盡矣...」。 
characteristics which would reveal these classics, for they are closer to elements that form the essence of sinicized Buddhism teachings.

In the traditional Chinese understanding and interpretation concepts that include the notion of emptiness and the unmentionable "path" (Dao) can be close to complex Buddhist ideas such as the idea of illusionary existence or the idea of non-existence. Thus Dao, the materialisation and unity of which forms the original beginning as well as the final level of any existing condition, represents the central principle in the classic Daoist thought, to which it all strives and to which it all returns. The wholesome and all encompassing affirmation of the existence of this principle or goal includes the existence of the all-encompassing negation, which limits the appearance of the pre-determined object or goal. The guideline to which this negation leans is not oriented towards denying the essence of the substance, but is, on the contrary, applied to rejecting the negative essence of Dao's materialisation. The original, i.e. real characteristics, which strive to return to the concrete and materialised substance need to penetrate these elements of negation; this is how negation is negated. This theoretical system has provided concrete conditions and a method for fulfilling the regression from materialisation to the true (actual) condition, i.e. merging cosmic and subjective factors, already within the system of classical Daoism.

The annihilation of all affirmation is of central importance for the development of sinicized Buddhism, for regardless of the completeness of the individual concepts this forms the methodological core of classic Daoist dialectics. Any affirmation is understood as a closed definition, as a basis for closed thought (or language) constructs. Buddhism and Daoism share the principle of radical openness, which forms the basic precondition for breaking through consciousness. Methods used in Buddhist logic and the complementary dialectics of Daoist classics attempt to surpass these limitations.

The difference between the two systems becomes clearly visible in the qualitative analysis: while the semantic structure of the Buddhist negations dictates the negation of both poles of the bipolar dialectics ( $\mathrm{x}$, as well as not- $\mathrm{x}$ ), the classical Daoist concepts of absence (wu) and forgetfulness (wang) of reality do not represent the negation of everything in the absolute sense, but merely the negation of the persistent attachment to objects of existing reality through forgetfulness of the perception of appearance which also includes the wishes that are the result of this attachment. This is a specific concept in classical Daoism, which still represents a reflection of the proto-philosophical thought of traditional China. The method of fasting the heart-mind allows one to achieve the state of absence and represents an important bridge between the Chinese classics and Buddhist ideas. According 
to Chinese classics this method can be achieved through oblivion (wang), which at first glance appears to be in opposition to the preservation of the given forms of consciousness (i.e. with some sort of memory), but which comes to the forefront with the term mindfulness. However, we need to be careful, for Daoist oblivion is linked merely to the forgetfulness of thoughts, desires and the constantly changing forms of appearance. The fasting of the heart-mind, which enables the oblivion of forms (including the limitations of self and the manifestations of its consciousness), is shown in the preservation of the emptiness, i.e. in the continuous focus on the wholeness of the sprit, which is comparable to the idea of mindfulness as an idea of preserving a pure, undividable and undivided here and now presence.

\section{The Notion of Mindfulness in China}

The idea of mindfulness, which has formed within the frame of Indian Buddhism, is usually translated in Chinese Buddhist texts as nian (念), which represents a synonym for the Indian term (Pāli sati, Sanskrit smrti) (Sharf 2014, 939), or the term zhengnian (正念), which corresponds to the Pāli sammā-sati or the Sanskrit samyak-smrti. In pre-Qin texts, i.e. in original Chinese texts that were written prior to the arrival of Buddhism, this term had an array of different meanings. We are going to start with the analysis of these meanings and their connotations within the frame of semantic research, which will originate from the original, i.e. etymological meaning of the term nian 念. In this step we will focus on the research of its connotations as the word developed. The development of the word is truly fascinating, for the etymological structure of the Chinese character that expresses it is created from radicals that stand for the (a) present and (b) heart-mind. In this sense the translation is close to the basic connotations of the terms sati or smrti, for the etymology of this Chinese character is certainly linked to the preservation of the current moment in the (heart) mind of an individual.

In ancient (pre-Qin ${ }^{21}$ ) sources this Chinese character was most commonly used to denote the memory or remembering/preserving something (or someone) in the thoughts, which is also one of the central meanings of both previously mentioned Indian terms. However, it was often used to mean an idea and/or thought already in the oldest original sources. It is this latter meaning that most likely led for the term nian to be used in modern Chinese language predominantly in meanings that have no direct link with the idea of mindfulness--on

21 This term is a translation of the Chinese expert term (xian Qin 先秦時代), which denotes the classical era of Chinese philosophy during the Eastern Zhou Dynasty (Dong Zhou 東周, 770-256 $\mathrm{BCE}$ ), i.e. original Chinese philosophy that was present prior to Buddhist influence. 
the contrary: in modern Chinese language this term mainly appears within compounds $\mathrm{s}^{22}$, such as for instance: gainian 概念 (concept), yinian 意念 (idea, meaning), buainian 懷念 (lusting for someone, missing) etc.

Firstly we will take a closer look at how this character ${ }^{23}$ was used by the main classic writers in the pre-Qin era, at which we will focus on the most influential philosophical schools or ideas and the most important philosophers within each one of them ${ }^{24}$ :

1. Proto-philosophical classics: Book of Poetry (Shi jing), Book of Documents (Shu jing), Book of Changes (Yi jing).

2. Confucianism: The Analects of Confucius (Lunyu), Mencius/Master Mencius/ (Mengzi), Master Xun (Xunzi), and Book of Rites (Li ji).

3. Philosophical or classical Daoism: Laozi's The Classic of the Way and Its Virtue (Dao de jing), Zhuangzi's The True Classic of Nan Hua (Nan hua zhen jing) ${ }^{25}$.

4. Legalism: Master Han Fei (Han Feizi), The Book of Lord Shang (Shang jun shu), Shen Buhai

5. Moism: Master Mo (Mozi)

6. School of Names: Master Gongsun Long (Gongsun Longzi), Master Deng Xi (Deng Xizi)

7. Medicine: The Emperor's Inner Canon (Huang di nei jing)

Ad 1. The term nian 念 appears 65 times in proto-philosophical classics, i.e. 28 times in the Book of Poetry and 37 times in the Book of Documents, while the Book of Changes does not register a single occurrence of the term.

22 While classic Chinese language mainly used monosyllables, which means that each syllable, which corresponds to one character in writing, represented one word with a specific meaning, the development of Chinese language started showing tendencies that lead to compounds already during the first centuries CE. In contemporary Chinese language monosyllables represent a mere $10 \%$ of all words. The development of establishing word classes ran parallel to this development. In classical Chinese the meaning was most commonly dependent on the context, and an individual expression could usually appear in various word categories. This changed in contemporary Chinese language, in which the meanings of the words are usually connected to a certain word category, similar to Indo-European languages.

23 This overview was created with the aid of the Chinese text project webpage and its software tools.

24 All of the classic texts mentioned below have been digitalised for the Chinese text project webpage, thus they will not be additionally mentioned in the bibliography of this article, with the exception of those from which we have used concrete quotes.

25 Syncretic works such as Liezi, Huai Nanzi and Wenzi will not be taken into account at this point, even though they are often included amongst the classics of philosophical Daoism; however, new research has shown that most of these works have emerged only after the pre-Qin period (mainly during the Han dynasty) and already include a lot of Buddhist influences. 
Ad 2. This term appears nine times in the Confucian classics, i.e. once in The Analects of Confucius, twice in Xunzi, six times in the Book of Rites and not a single time in Mengzi.

Ad 3. The term appears a single time in the classics of philosophical Daoism, for it appears once in Zhuangzi's The Pure Classic of Nan Hua.

Ad 4. The term nian was used a single time in the classics of the Legalist School-it appears in the Master Han Fei.

Ad 5. This term was not used in Moism.

Ad 6. This term was also not used in the School of Names.

Ad 7. The medical classic The Emperor's Inner Canon includes five mentions of the word nian.

This clearly indicates that the word nian did not hold any philosophical connotations in the pre-Qin period, i.e. before Buddhism arrived to China. It was used in one of the following two meanings (in all checked sources):

Thinking of, having somebody or something in one's thoughts;

Remember.

The term nian was explained with these meanings also in the three main classic Chinese language dictionaries ${ }^{26}$ : the early second century Shuowen Dictionary (Shuowen jieci 說文解字) ${ }^{27}$, the early eleventh century encyclopaedia Broad rhymes (Guang yun 廣韻) ${ }^{28}$ and the early eighteenth century Kangxi Dictionary (Kangxi zidian 康熙字典 $)^{29}$.

26 These were also digitalised for the Chinese text project webpage and will thus not be mentioned separately in the bibliography.

27 念: 常思也. 從心今聲 (Nian: Have in mind, constantly think of someone or something. Compiled from the heart-mind and the present).

28 念: 思也. 又姓西魏太傅念賢。(Nian: Think of, think. Also the pronunciation of the surname Xian)

29 Alongside the previously mentioned examples this dictionary also mentions 黏也 as a semantic connotation of the term nian 念. The character 黏 is also pronounced nian, and means to "be glued". This state of being glued is further explained with the phrase 意相親愛, 心黏不能忘也 (reciprocal love, being glued and finding it impossible to forget). The most important fact for this discussion is that this dictionary also mentions the meaning of the word nian, taken from the third century hermeneutic encyclopaedia Xiao er ya 小爾雅, in which this term is explained with the following phrase: 無念, 念也. (To be without thoughts /memory, attachment / equals to thought, memory, attachment). This might have been an early influence of Buddhism, for in numerous later as well as contemporary Buddhist sources the expression nian is explained in a similar way (see e.g. 「無念者 一切處無心是, 無一切境界, 無餘思求是, 對 諸境色, 永無起動, 是即無念。無念者是 
Let's take a look at a typical example of its use within Confucianism and Daoism, i.e. to those Chinese philosophical thoughts that formed the meaningful and methodological bridges for the sinicization of Buddhist teachings-in both discourses the word nian was obviously understood (and used) in the sense "to have (something or someone) in the thoughts" or "to remember": "The master said: "Bo $\mathrm{Yi}$ and Shu Qi never preserved grudges in their memories, thus people did not complain about them very often'." (Kongzi 2015, Gongye chang, 23) ${ }^{30}$. "Due to their desire for fame they died recklessly, and none of them had nursing or caring for their lives in mind." (Zhuangzi 2015, Za pian, Dao Zhi, 1) ${ }^{31}$.

\section{Mindfulness and Chinese Buddhism}

In the sense of a meditation technique this term established itself only through Buddhism, i.e. through religion and philosophy that do not belong to the "original" Chinese thought systems, for they emerged in India. However, during the two millennia of development since its arrival to China the Buddhist ideas and practices changed and influenced Chinese culture, especially in areas in which they were materially manifested, such as philosophy, literature, art and politics.

Most researches in Chinese Buddhism agree that Buddhism arrived to China by land; amongst the first who brought Buddhist religious and philosophical ideas to the Chinese soil were traders who travelled along the silk route during the first centuries CE. However, due to the lack of written sources Buddhism failed to spread amongst a wider circle of Chinese inhabitants at this point in time. This situation did not improve even with the first translations of Buddhist works; on one hand these translations were usually based on the Daoist terms and referential frames and were thus often misleading ${ }^{32}$, while on the other Buddhism was an alien philosophy for the pragmatic Chinese with a positive outlook on life. It was only in the third century that the elite circles of Chinese intelligentsia started gradually taking Buddhist sources more seriously. The vast translations of Indian Buddhist materials into Chinese had-together with the works that were

名眞念也。若以 (無) 念為念者, 即是邪念, 非為正念。」To be without thoughts (memory) means that the heart-mind is not located in a space, it does not appear in any sort of state, i.e. it is without any redundant thoughts or desires, and is not stimulated by any phenomenon. This is the lack of thought /memory. If we fulfil this lack of thought/memory as a thought/memory, we obtain true, elevated thought/memory-and this is the true thought/right memory (true mindfulness). (Liu 2015, 1)

30 子曰: 「伯夷、叔齊不念舊惡, 怨是用希。

31 皆離名輕死, 不念本養壽命者也。

32 We will discuss this issue at a slightly later stage. 
created in China-long-lasting consequences on the spread of Buddhism across the broader area covered by the Chinese cultural influence, including Korea, Japan and Vietnam. Post fourth and fifth century China witnessed the establishment of numerous Buddhist schools, amongst which the following where the most important:

1. Ju she zong 俱舍宗 (Kosa Sarvāstivādin);

2. Cheng shi zong 成實宗 (Sautrāntikas);

3. Fa xiang zong 法相宗 (Madhyama-yāna);

4. San lun zong 三論宗 (Āryadeva, the School of Master Nāgārjune);

5. Hua yan zong 華言宗 (Avatamsaka);

6. Tian tai zong 天台宗;

7. Lü zong (Vinaya) 律宗;

8. Jing tu zong 淨土宗 (The School of Buddha Amithābe);

9. Zhen yan zong 真言宗 or Mi zong 密宗 (The School of Mystery; Tantra—or Mantra-School);

10. Chan zong 禪宗 (Dhyāna)

The latter is the most important for this discourse, for it emphasises the role of meditations and does not depend on the studies of written sources, but is based on the direct transfer of knowledge through consciousness ${ }^{33}$. Even though this school originated in China the West most commonly knows it by its Japanese name Zen. ${ }^{34}$ At the same time as this school, which was established in the sixth century $\mathrm{CE}$ and that is often perceived as a synthesis of Buddhism with Confucian and Daoist elements, started to flourish, the Tang Dynasty came to power (618-907). Within the field of traditional culture and thought, this period represented one of the liveliest and most open periods in Chinese history. The spiritual atmosphere, which prevailed during this period, and which was to a certain degree conditioned by the opening of the trade routes that connected the Central State with Central and South East Asia, encouraged research and integration of new, foreign ideas and systems into Chinese thought. During these three centuries Buddhism-and especially the Buddhism of the Chan School-found its roots in China and experienced its greatest growth and development (Rošker 2005, 236).

Even though the name Chan originates from old Indian Buddhism, in which it represents the translation of the term dbyana (the state of focused consciousness and simultaneous lack of thoughts and emotions in meditation), the philosophical

33 The main principles of this school of thought include the negation of written documents (不立 文字) and individual, personal transfer of insights from the master to the pupils through a direct contact of their consciousness (直指人心).

34 The Japanese pronunciation of the character 禪, which is in Chinese pronounced chan. 
system of Chan is in fact a sinicized branch of the Buddhist teaching, which started developing in sixth century China almost entirely independently. As previously mentioned, most experts believe that Chan emerged as a specifically Chinese synthesis of Buddhist, Daoist and Confucian elements.

One of the basic postulates of this philosophy lies in the incapability of the written mediation of any relevant contents on the language, i.e. on the conceptual level. Even though Chan rejects all written records and literature, including learning and writing Buddhist sutras, this formed the system frame for the future development of numerous classical Chinese, especially Daoist epistemological approaches. The method of mediation, as advocated by Chan philosophy, can take place only on the individual level and remains a private matter between the teacher and pupil. However, most masters of Chan Buddhism (including the illiterate Huineng) left the generations to come sutras that included their ideas. Apart from this the Chan school of Buddhism is based on the theoretical starting points of the Diamond sutra (Jin gan jing), in which the term nian appears relatively often. However, in the Chinese translation of the ancient Indian text this word is most commonly used to mean memory or thought. For a better understanding let's take a look at a few typical examples of its use found in this work, which represents the oldest printed book in the world:

You said it right: Tatagata always has all bodhisattvas in his thoughts (nian); he protects them and offers them good advice (Jingan jing 2015, 2) ${ }^{35}$.

What do you think, Subhuti? Can Sakridāgāmi think (nian) ${ }^{36}$ to himself: will I receive the fruits of Srotāpanne? (ibid., 9) ${ }^{37}$

Subhuti,I remember (nian) the endless past of Buddha Dipankare. (ibid., 16) 38

Don't think (nian) this! (ibid., 21, 27) 39

The use of the term nian differed slightly in a single case, in which it was indirectly linked to the idea of religion, thus it would be more appropriate to translate it with the word spirit: "Subhuti, at the very moment people will hear this teaching, pure religion will be born in their spirit (nian)!" (ibid., 6) 40 $^{40}$

35 如汝所說: 如來善護念諸菩薩, 善付囑諸菩薩.

36 Literary: make this thought.

37 須菩提！於意云何? 須陀洹能作是念：我得須陀洹果不?

38 菩提！我念過去無量阿僧祇劫.

39 莫作是念!

40 聞是章句, 乃至一念生淨信者; 須菩提！ 
However, in the sense of mindfulness as a meditation technique this term is found as late as in the work entitled $R u$ Dao anxin yao fangbian famen ${ }^{41}$ (Basic and Efficient Teachings for Calming Down the Heart-mind in the Joining with Dao), which emerged from under the pen of Daoxin, the fourth patriarch of Chan Buddhism (cf. Sharf 2014, 939). In the beginning of the book Daoxin (580-651) stated: "Buddha preserves the heart-mind in mindfulness that is Buddha. Those whose thoughts are confused remain normal." (Daoxin 2015, 1) ${ }^{42}$.

A few sentences later he explained this in greater detail: "Preserving Buddhist mindfulness (nian) is mindfulness (nian) that does not have an object (ibid.) ${ }^{43}$.

And what does mindfulness without an object mean?

There is no Buddha outside of the heart-mind. There is no heart-mind outside of Buddha. Reflecting on Buddha is identical to reflecting on the heart-mind. To seek the heart-mind is to seek Buddha. Why is this so? Consciousness is without form. Buddha is also without form and without manifested attributes. To understand this principle is to pacify the mind. (ibid., 1-2) ${ }^{44}$.

In the continuation Daoxin described the meditation technique based on such mindfulness in great detail. In this part we can also find one of the mentions (rare in Chan Buddhism) of the term zhengnian 正念, which stands for "right mindfulness" and represents, as we have previously mentioned, the Chinese synonym or translation of the Pal concept of sammā-sati or the Sanskrit samyak-smrti. "Heart-mind is continuous at every moment, mindfulness (nian) is not merely temporary; the right mindfulness (zhengnian) does not stop and is manifested in front of us ${ }^{45}$."

With the fourth patriarch the mindfulness method established itself in China as a meditation technique that leads to enlightenment, i.e. to the recognition of one's Buddhist nature, to Buddhism. Daoxin, who is known as a member of the Chan tradition of the East Mountain (Dong shan 東山, cf. Sharf 2015, 935), was the master of Chan Buddhism who introduced the term nian as a synonym for mindfulness in the sense of the Sanskrit term smrti. This meditation method remained in the foreground of the Chen meditation for almost one hundred years after his death, i.e. also in the period of his successor Hongren (601-674), the

41 入道安心要方便法門

42 即念佛心是佛, 妄念是凡夫。

43 無所念者, 是名念佛.

44 何等名無所念。即念佛心名無所念。離心無別有佛。離佛無別有心。念佛即是念心。求心 即是求佛。所以者何。識無形。佛無形。佛無相貌。若也知此道理。即是安心....

45 心心相續, 無暫間念, 正念不斷, 正念現前。 
fifth patriarch of Chan Buddhism. The (assumed) break with this tradition occurred only with the successor of the latter, i.e. with the sixth patriarch Huineng (638-713). Let's take a look how this occurred and why this break might not be as radical as it is interpreted by most later sources.

\section{Southern School of Chan Buddhism: Lack of Mindfulness or Lack of Thoughts?}

The beginnings of Chinese Chan Buddhism reach into the sixth century:

This meditation school was established in $520 \mathrm{CE}$ by the 28th Patriarch Bodhidharma who arrived to China. He did not want to even hear about the studies of the holy sutras. He was only interested in getting to know his own nature and mind. In this way he could obtain true knowledge and become Buddha. For this purpose he had to perform certain types of meditations, which lead to wisdom (prajiñ $\bar{a}$. The theory of meditations was passed to the pupils orally, however collections by various known dhyāna - teachers do exist. This theory was for the "higher" minds what amitism was for the masses. Its meaning for Chinese and Japanese thought and spirituality is invaluable. (Forke 1934,194)

There is not a lot of historically verifiable data on Bodhidharma, who is considered to be the first patriarch of Chan Buddhism, however with the development and growing importance of the Chan tradition in the early eighth century (McRae $2003,4)$ his hagiography became increasingly detailed. The official pedigree of the traditional patriarchs of this school was composed in the late eighth century under the influence of Shenhui, a pupil of the sixth patriarch (ibid., 3):

1. Bodhidharma (達摩) approx. 440-approx. 528

2. Daizu Huike (慧可) 487-593

3. Sengcan (僧燦)?-606

4. Dayi Daoxin (道信) 580-651

5. Daman Hongren (弘忍) 601-674

6. Huineng (慧能) 638-713

In the seventh century (during the Tang dynasty period (618-907)), the school split into two under its last patriarch; Huineng's rival Shenxiu, a representative of the Northern School, defended the concept of persistent, continuous and practically oriented meditation, while Huineng, who became the last, i.e. sixth patriarch of the Chan School, advocated the stream that he founded and which became 
known as the Southern Chan School. The latter was not based merely on meditation practices, but also on philosophical speculations (cf. Forke II, 194); the school advocated a new concept, which was introduced by Huineng, i.e. the concept of momentary enlightenment. According to tradition the difference between the two concepts can be clearly seen in the four-liners that were written by the two monks once their master Hongren, the fifth patriarch of the Chan School, published that his position will be inherited by the monk who will provide the best description of the essence of Chan in a short poetry form. Shenxiu's poem read as follows:

The body is a Bodhi tree

The mind a standing mirror bright.

At all times polish is diligently,

And let no dust alight. ${ }^{46}$ (Huineng 2015,2)

Huineng responded with his own verses:

Bodhi is originally without any tree.

The bright mirror is also not a stand.

Originally there is not a single thing-

Where could any dust be attracted?. ${ }^{47}$ (ibid.)

The traditional interpretation, which emerged at the beginning of the ninth century from under the pen of the Buddhist philosopher Zongmi, thus presumes that Shenxiu's poem expresses support to the gradualistic, while Huineng's poem expresses support to the subtistic method of achieving enlightenment. However, numerous contemporary theoreticians (see for instance McRae 2003, 64) do not agree with this idea. When interpreting this part of the story recorded in the Sutra Platforms, which is believed to be the work of the sixth patriarch, one should take into account the fact that his poem in itself does not have a specific meaning, but only obtains a meaning in relation to Shenxiu's poem, i.e. as a response or a reaction to it. Together the two four line poems form an entity composed of two parts, which can be understood as mutually opposing or complementary. Why does Huineng's response fail to address gradualism ${ }^{48}$, which can clearly be seen in the

46 身是菩提樹, 心如明鏡臺, 時時勤拂拭,勿使惹塵埃.

47 菩提本無樹, 明鏡亦非 臺, 本來無一物, 何處惹塵埃.

48 In his platform sutra Huineng rejected this categorisation when he said: "Dear friends! The right teaching does not differentiate between gradual and momentary enlightenment. Humans have different natures: some are brighter than others. Those who have strayed, continue gradually, while those who already have insight, practice methods of momentary enlightenment. When you realise what your heart-mind is, when you see your deepest nature, these differences will cease to exist. This is why subitism and gradualism are merely provisory categories." (Huineng 2015, IV-17). (善知 識！本來正教, 無有頓漸, 人性自有利鈍。迷人漸契, 悟人頓修, 自識本心, 自見本性, 
"time and time again wiping of the mirror", which represents the human spirit or the human consciousness, but instead focuses on the dualism of body and spirit, in which the endeavours for achieving enlightenment take place. In his four-liner Huineng does not expose merely the illusory nature of the physical, i.e. material body, but also the emptiness or the non-existence of the mind as such.

In this radicalised version of the Buddhist learning we can also notice the autochthonous Chinese tradition of Daoist and Confucian classics. We should remember the previously mentioned description of the fasting of the heart-mind, in which Zhuangzi placed the following words into the mouth of Confucius: "Let your heart-mind remain merely a symbol" (Zhuangzi 2015, Renjian shi, 2) ), $^{49}$ which can be understood as the annihilation of the existence of actual consciousness; one should also keep in mind that this method leads into the void, which can also be found in the centre of Huineng's four-liner. The illiterate Huineng never got acquainted with all of the classical works of the Mahayana Buddhism, and yet he managed to create a thought system which led this branch of Buddhism to a new, deeper and at the same time coherent climax. The same holds true for the autochthonous Chinese classics: Huineng never studied them explicitly. However, as these classics represented one of the central cultural heritages of China in his time, he had to learn the basic Daostic and Confucian concepts and their basic spiritual orientation during his socialisation process (ibid., Xu Xiaoyue 1996, 217).

Of course, this assumption is also closely linked to Huineng's relation to mindfulness. Numerous researchers of Buddhist philosophy assumed that this differs greatly not only from Shenxiu's interpretation of this meditation technique, but also from the similar positions of all previous Chan School patriarchs, at which the positions of the fourth (Daoxin) and fifth (Hongren) patriarchs deserve a special mention, for they established mindfulness as the central meditation technique on the path to enlightenment (Sharf 2014, 938; McRae 1986, 262)

The difference between the North and South School does thus not lay merely in advocating the reciprocally opposing methods of gradualism and subitism, (which was, as we have seen previously (see footnote 47), denied already by the founder of the South School), but also in their positions as regards meditation and mindfulness:

The East Mountain and Northern Chan masters availed themselves of the mirror analogy in their explications of practice. Rather than engaging the transitory images that appear, one must, from moment to moment,

即無差利, 所以立頓漸之假名。) 
focus on the innate purity of mind-the seeming transparence of conscious awareness itself. Such practice is intended, among other things, to undermine the givenness of the external domain, along the lines of "representation-only" (vijñaptimatra) or mind-only (cittamatra) teachings. The subitists reject this approach, since it simply substitutes one givenness (that of the mind) for another (the world). In something akin to the deconstruction of the metaphysics of presence, the subitists insist that mind, too, cannot be attained (bu ke de 不可得), and thus even notions such as "mindfulness" and "maintaining unity" must be abandoned (ibid., 951).

The texts of the South School of Chan Buddhism often negate the term nian (which is most commonly equalled to the concept of mindfulness and is, for example, always used in this sense in the previously mentioned Daoxin's work). It appears that in his Platform sutra Huineng did not equal the term nian with mindfulness. It is much more likely that Huineng did not consider mindfulness in this negation, but simply thought, the conceptual understanding of reality. Let's take a look at a few paragraphs in which the term nian is explicitly negated:

Dear friends! In the past our teaching has indicated that it primarily emphasises the lack of thought (nian). Its essence can be found in the lack of appearance and its base is represented by the lack of support or attachment. The lack of appearance means to separate oneself from appearance in the midst of appearances; the lack of thought (nian) means to be without thoughts (nian) in the midst of thoughts (nian); the lack of support or attachment represents the deepest human nature, which means the following: even though we are-in a world that differentiates between good and evil- exposed to injustices and slander, we can see that everything is empty and thus not search revenge (Huineng 2015, IV-17)..$^{50}$

Dear friends! When the heart-mind is not tarnished by any states, this is called a lack of thoughts (nian). This means to rise above one's own thoughts (nian), and surpass all restrictions of the various states in our heart-mind. If we do not think the hundred thoughts (nian), the thought (nian) will wear out and all thoughts (nian) will disappear. Don't believe you are going to die and be reborn as soon as the flow of your thoughts (nian) is broken, for this is not true. Think about it, you who are learning

50 「善知識! 我此法門, 從上以來, 先立無念為宗, 無相為體, 無住為本。無相者: 於相而 離相; 無念者: 於念而無念; 無住者: 人之本性, 於世間善惡好醜, 乃至冤之與親, 言語 觸刺欺爭之時, 並將為空, 不思酬害.」 
the Path! If you fail to recognise your own mistakes while learning about dharma, you will also inflict this upon others. Whoever fails to see this puts the Buddhist classics into a bad light. Thus lack of thoughts (nian) is placed first. (ibid.) $)^{51}$

Dear friends! You wonder why I position such stress on the lack of thoughts (nian). When we discuss our deepest nature merely on the basis of our destiny, we can get lost in the multiple states of thought (nian). This provides us with erroneous insights and many illusions are born, and these re-establish the dust of reality and the torment connected to it. Not a single method exists in our deepest nature that could save us. If we think we have found it, this is merely an erroneous insight that originates from reality and its hardships. This is why I have established a method, which places the lack of thoughts (nian) first. (ibid., 18) ${ }^{52}$

In his writings on meditation Huineng also emphasised the lack of the term nian (i.e. the lack of thoughts):

Dear friends! What does it mean to sit in meditation? According to this method this is a state of total non-limitation, in which there are no borders, for it is a state beyond all good or evil. This state, in which not a single thought (nian) is raised, is (such) sitting. The motionless, unchangeable insight into one's own nature is called meditation (ibid., $\mathrm{V}-18)^{53}$.

However, in his sutra Huineng used the term nian also in a positive, affirmative sense. We encounter such affirmations almost exclusively in situations which deal with two repeated terms nian 念, i.e. in cases with the compound 念念. In the context of Huineng's sutra this could be translated with the term mindfulness, for those parts of the text in which Huineng uses this compound address a state that can be compared to what is in Buddhism understood as the mindfulness technique or method. If we take a look at a few examples of this use of the term niannian 念念 we can notice that a large majority of them deal with affirmation:

51 「善知識! 於諸境上心不染, 曰無念; 於自念上常離諸境, 不於境上生心。若只百物不 思, 念盡除卻, 一念絕即死, 別處受生, 是為大錯。學道者思之。若不識法意, 自錯猶 可，更勸他人，自迷不見，又謗佛經；所以立無念為宗。」

52 善知識! 云何立無念為宗? 只緣口說見性, 迷人於境上有念, 念上便起邪見, 一切塵勞 妄想, 從此而生。自性本無一法可得; 若有所得, 妄說禍福, 即是塵勞邪見。故此法門, 立無念為宗。」

53 善知識! 何名坐禪? 此法門中, 無障無礙, 外於一切善惡境界, 心念不起, 名為坐; 內見 自性不動, 名為禪。 
We persist in mindfulness (niannian) and do not think about the past states. When we have in mind an endless flow of reciprocally following (nian-nian) thoughts (nian), which are connected to the past, present and the future, we get tied down. With an appropriate use of methods we can persist in mindfulness (niannian) without attachment or support; in this way we untie and free ourselves. This is the importance of non-attachment as a basis (ibid., IV-17). ${ }^{54}$

Dear friends! Mindfulness (niannian) allows for the submersion into our pure and deepest nature. If we know how to nurture and perform this, we can find a part of Buddhism on our own. (ibid., V-19) $)^{55}$

Dear friends! You have gathered here today because of your nature! You should preserve mindfulness (niannian) at all times and purify your heart-mind; nurture it, perform it on your own and you will see your dharmakaya ${ }^{56}$ and get to know the Buddhism of your heart-mind. (ibid., VI-19) $)^{57}$

\section{Conclusion}

We have tried to show the connection between the classics of pre-Buddhist Chinese philosophy and the development of sinicized Buddhism by looking at mindfulness meditation techniques. The referencing on pre-Buddhist (especially Daoist and Confucian) philosophical classics is most visible in the ideas of Huineng, the sixth patriarch of Chen Buddhism and the founder of the South School, especially in his radicalisation of the (non)existence of consciousness as a precondition of entering or experiencing the void. We have also critically looked at the presumption, according to which the idea of mindfulness did not exist in autochthonous Chinese literature and we have stated an array of arguments, which speak in opposition to the traditional interpretations of the differences between the North and South Chan School of sinicized Buddhism. We have focused on the mindfulness concept and exposed the fact that-contrary to prevailing interpretations-Huineng, the founder and central representative of the South School

54 念念之中, 不思前境。若前念、今念、後念, 念念相續不斷, 名為晸縛。於諸法上, 念念 不住, 即無縛也。此是以無住為本。

55 善知識! 於念念中, 自見本性清淨, 自修自行, 自成佛道。

56 Literary: "true body" or "real body". In Mahayana Buddhism this represents one of the three bodies of Buddha; this aspect of Buddhism is not manifested and cannot be imagined.

57 於一切時, 念念自淨其心, 自修自行, 見自己法身, 見自心佛. 
of Chan, did not reject this concept. We have ascertained that he constantly rejected the term nian, with which the original Indian idea of mindfulness was usually translated into Chinese in the sources until then, for he understood it in its archaic meaning, as a thought, concept or idea. However, the analysis of his Platform Sutra has shown that he by no means denied the mindfulness technique as such, but he merely gave it a different name than his predecessors. Instead of using the term nian he described mindfulness with the compound niannian. If we look at classic Chinese language this compound could represent the connection between the verb and the noun. In this case it would, if we understand the syllable nian in its archaic meaning of thought or concept, mean "think a thought" or "conceptualise a concept". On the other hand, classical Chinese compounds created from two identical syllables or terms also express an uninterrupted flow of the state or action that the term expresses. Thus the term niannian can be understood as an uninterrupted flow of perception, composed of consecutive moments, which connect the thinking consciousness into a single unit, in which no individual, concrete thought can be found. Within this frame such renaming of the idea of mindfulness is a logical and sensible step and by no means in opposition to the original meaning of the Chinese character nian.

On the other hand, this aspect also speaks in favour of the re-interpretation of the content differences between the North and South School of Chan Buddhism, according to which the conflict as regards mindfulness and its absence (similar to the assumed conflict as regards the gradual and momentary method of enlightenment) is in its essence merely of a terminological nature and not truly linked to the contents or methods.

\section{References}

Chinese Text Project. 2015. Pre-Qin and Han. Accessed July 3, 2015. http://ctext. org/pre-qin-and-han.

Daoxin 道心. 2015. Ru Dao anxin yao fangbian famen 入道安心要方便法門. Accessed July 3, 2015. http://www2.budaedu.org/newGhosa/C003/T034A/ref/ T034A_128.pdf.

Ditrich, Tamara. 2016. "Buddhism between Asia and Europe: The Concept of Mindfulness through an Historical Lens.” Asian Studies 4 (1): 197-213.

Forke, Alfred. 1934. Geschichte der mittelalterlichen chinesischen Philosophie (II). Hamburg: R. Oldenbourg Verlag.

$\mathrm{Hu}$, Xuezhi. 2006. Revealing the Tao Te Ching: In-Depth Commentaries on an Ancient Classic. New Delhi: Sevenstar Communications. 
Huineng 慧能. 2015. Liu zu dashi fabao tanjing 六祖大師法寶壇經. Accessed July 7, 2015. http://club.ntu.edu.tw/ davidhsu/New-Davidhome/05-david-book/DAVIDBOOK /CHINESE/001david-new-book/SIXTH.pdf.

Jingang banruo polomi jing 金剛般若波羅蜜經. 2015. (Vajracchedika Prajnaparamita Sutra). Accessed July 3, 2015. http://www.obf.org.tw/article/UA/UA02_ \%E5\%85\%A7\%E6\%96\%87.pdf.

Kongzi 孔子. 2015. Lunyu 論語. The Chinese Text Project, pre-Qin and Han. Accessed July 3, 2015. http://ctext.org/analects.

Laozi 老子. 2015. Dao de jing 道德經. The Chinese Text Project, pre-Qin and Han. Accessed July 3, 2015. http://ctext.org/dao-de-jing.

Legge, James 2015. "Translation of Daode jing." In The Chinese Text Project, pre-Qin and Han. Accessed July 3, 2015. http://ctext.org/dao-de-jing.

Liu, Chengfu 劉承符. 2015. Tan wu nian 談無念. Vajra Bodhi Sea. Accessed June 30, 2015. http://www.drbachinese.org/vbs/publish/180/vbs180p017c.htm.

McRae, John. 1986. The Northern School and the Formation of Early Ch'an Buddhism. Honolulu: University of Hawaii Press.

- 2003. Seeing through Zen. Encounter, Transformation, and Genealogy in Chinese Chan Buddhism. Berkeley and Los Angeles: University of California Press.

Rošker, Jana. 2005. Iskanje poti: spoznavna teorija v kitajski tadiciji. 1. del. Od protofilozofkih klaiskov do neokonfucijanstva dinastije Song. Razprave Filozofske fakultete. Ljubljana: Znanstveni inštitut Filozofske fakultete.

- 2012. "Structure and Creativeness: a Reinterpretation of the Neo-Confucian Binary Category Li and Qi." In Origin(s) of Design in Nature: A Fresh, Interdisciplinary Look at How Design Emerges in Complex Systems, Especially Life, edited by Liz Swan Stillwaggen et al. 273-85. Dordrecht et al.: Springer.

Sharf, Robert. 2014. "Mindfulness and Mindlessness in Early Chan." Philosophy East Eं West 64 (4): 933-64.

Slingerland, Edward. 2003. Effortless Action: Wu-wei as Conceptual Metaphor and Spiritual Ideal in Early China. Oxford: University Press.

Xu, Xiaoyue 徐小躍. 1996. Chan yu Lao Zhuang 禪與老庄. Hangzhou: Zhejiang renmin chuban she.

Zhuangzi 莊子. 2015. Nan hua zhen jing 南化真經. Chinese text project, pre-Qin and Han. Accessed July 3, 2015. http://ctext.org/zhuangzi. 